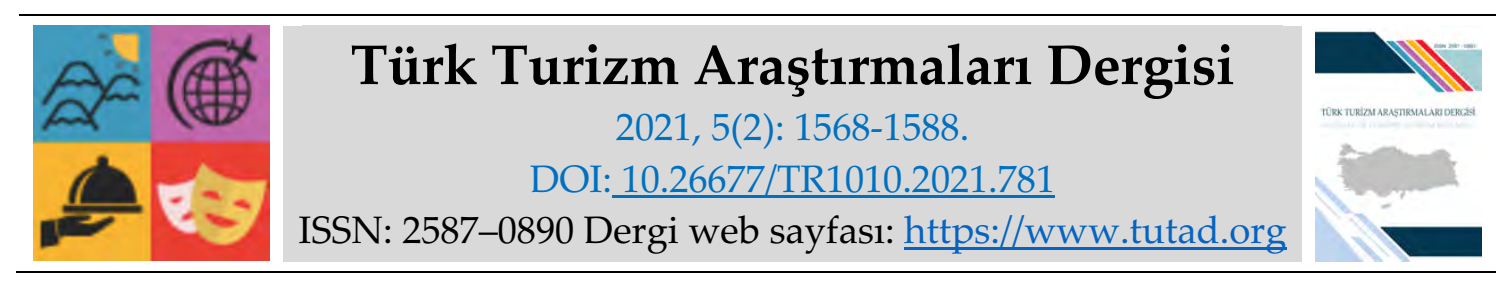

ARASTIRMA MAKALESI

\title{
Trakya Bağ Rotasında Bulunan İşletmelerin Hizmet Kalitesinin Ölçümüne Yönelik Bir Araştırma
}

Dr. Öğr. Üyesi Nilüfer VATANSEVER TOYLAN, Kırklareli Üniversitesi, Turizm Fakültesi, Kırklareli, e-posta: nilufer.vatansever@klu.edu.tr ORCID: https://orcid.org/0000-0003-2217-8267

Kubilay Can ERTÜRK, Yüksek Lisans Öğrencisi, Kırklareli Üniversitesi, Sosyal Bilimler Enstitüsü, Kırklareli, e-posta: kcan94@hotmail.com

ORCID: https://orcid.org/0000-0003-2799-5469

Öz

Bu çalışma, şarap turistlerinin Trakya Bağ Rotasında bulunan işletmelere yönelik hizmet almadan önce beklentileri ve aldıktan sonra algıları arasındaki farkın Servqual ölçeği ile ortaya konmasını amaçlamaktadır. Verilerin elde edilmesinde, kolayda örneklem yöntemi kullanılmıştır. Bu kapsamda, 2019 yılı boyunca, Trakya Bağ Rotasında bulunan 12 işletmeyi ziyaret eden 276 şarap turistinden, yüz yüze ve internet ortamı ile anket uygulanarak veriler elde edilmiştir. Araştırma bulgularını ortaya koyabilmek için güvenirlik, geçerlilik, farklılık ve ilişki analizlerinden yararlanılmıştır. Servqual analizine dayanarak müşteri beklentileri ile algılanan hizmet kalitesi arasında oluşan en büyük farklar, servqual fark puan ortalamalarına göre sırasıyla fiziksel özellikler ve heveslilik, güvence ve empati ve güvenirlik boyutları olmuştur. Wilcoxon analizine göre sadece güvence boyutunda ziyaretçilerin bağ işletmelerinin hizmet kalitesi konusunda beklediği güvence boyutunun, algılanan güvence boyutundan pozitif yönlü ayrıştığ1 ortaya çıkmaktadır.

Anahtar Kelimeler: Servqual Ölçeği, Beklenen Hizmet, Algılanan Hizmet, Şarap Turizmi, Trakya Bağ Rotası.

Makale Gönderme Tarihi: 07.02.2021

Makale Kabul Tarihi: 02.06.2021

\section{Önerilen Atıf:}

Vatansever Toylan, N. ve Ertürk, K. C. (2021). Trakya Bağ Rotasında Bulunan İşletmelerin Hizmet Kalitesinin Ölçümüne Yönelik Bir Araştırma, Türk Turizm Araştırmaları Dergisi, 5(2): 1568-1588.

(C) 2021 Türk Turizm Araştırmaları Dergisi. 


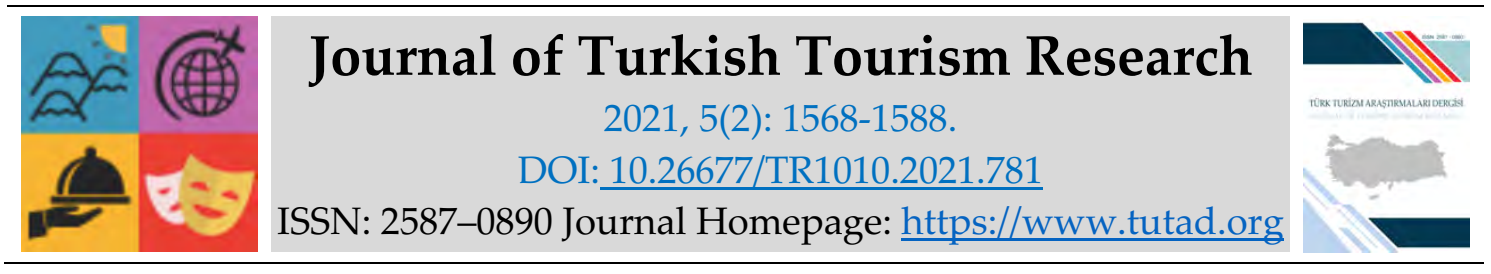

\title{
$\underline{\text { RESEARCH PAPER }}$
}

\section{A Research on the Measurement of the Service Quality of the Enterprises Located on the Thrace Vineyard Route}

Assistant Prof. Dr. Nilüfer VATANSEVER TOYLAN, Kırklareli University, Faculty of Tourism, Kırklareli, e-mail: nilufer.vatansever@klu.edu.tr ORCID: https://orcid.org/0000-0003-2217-8267

Kubilay Can ERTÜRK, MSc. Student, Kırklareli University, Social Sciences Institute, Kırklareli, email: kcan94@hotmail.com

ORCID: https://orcid.org/0000-0003-2799-5469

\begin{abstract}
This study aims to reveal the difference between wine tourists' expectations before receiving service and their perception after receiving service with the Servqual scale. The convenience sampling method was used to obtain the data. In this context, data were obtained from 276 wine tourists who visited 12 establishments on the Thrace Vineyard Route, through face-to-face and internet environment surveys throughout 2019. Reliability, validity, difference and relationship analyzes were used to reveal the research findings. Based on the Servqual analysis, the biggest differences between customer expectations and perceived service quality were the physical characteristics and enthusiasm, assurance and empathy and reliability dimensions, respectively, according to the servqual difference score averages. According to the Wilcoxon analysis, it was revealed that there is only a difference in the confidence dimension. The confidence dimension that visitors expect for the service quality of the vineyard businesses is positively differentiated from the perceived confidence dimension.
\end{abstract}

Keywords: Servqual Scale, Expected Service, Perceived Service, Wine Tourism, Thrace Vineyard Route.

Received: 07.02.2021

Accepted: 02.06.2021

\section{Suggested Citation:}

Vatansever Toylan, N. and Ertürk, K. C. (2021). Research on the Measurement of the Service Quality of the Enterprises Located on the Thrace Vineyard Route, Journal of Turkish Tourism Research, 5(2): 1568-1588.

(C) 2021 Türk Turizm Araştırmaları Dergisi. 


\section{Gíriş}

Şarap turizmi ile ilgili ilk çalışmanın "Wine tourism on the Moselle" başlığ 1 ile Becker tarafından 1984 yılında yapıldığı görülmektedir. Şarap turizmi 1990'lı yıllarda gelişim göstermeye başlamış ve kitle turizmi için önemli bir alternatif turizm türü olarak karşımıza çıkmıştır. Birçok kaynakta “özel ilgi turizmi” (Hall ve Weiler, 1992; Yüncü, 2010; Kozak ve Bahçe, 2012; Ergüven vd., 2016) olarak gösterilen şarap turizmi, kapsamlı olarak turizm ve şarap üretimi uygulamalarının birleşmesiyle ortaya çıkmıştır (Yıldız, 2009). Şarap turizmi ile ilgili çalışmalar 1998 yılında Avustralya'da düzenlenen ilk şarap turizmi konferansı kapsamında hız kazanmıştır. Aynı yıllarda konuyla ilgili önemli çalışmalar yapıldığı görülmektedir (Gilbert, 1992; Hall vd., 1997). Bunu takip eden yıllarda turizm olarak destinasyonların geliştirilmesi, özellikle turizmin alt kolu olarak şarap turizminin destinasyon alanlarının çoğaltılması konusunda araştırmalar yapılmıştır (Getz ve Brown, 2006).

Genel olarak hizmetler gibi turizmle ilgili hizmetlerde kalite kavramı, temelde müşteri algılarını ve beklentilerini dengelemekle ilgilidir. Başarılı hizmet sağlayıcılar, tüketicilerin beklentilerini karşılayabilir ve mümkün olduğunda bu beklentilerin ötesine geçebilir. Turizm ve eğlence sektörünün büyümesi, talebi artıran sosyal faktörlerden ve toplu seyahat ve boş zaman eğlencelerini mümkün kılan teknolojiden kaynaklanmaktadır. Bu bağlamda insanlar klasik turizm ürünlerinden ziyade alternatif turizm ürünlerine yönelmektedir. Bu ürünlerden biri olan şarap turizmi dünya çapında önemli bir cazibe merkezi haline gelmiştir. Bu nedenle mükemmel ürünler ve çevre sağlamanın yanı sıra, turistleri çekmek için yüksek düzeyde müşteri memnuniyeti sağlama gerekliliği (Jinling, 2006: 257) şarap turizmi kapsamında sunulan hizmetler için de söz konusudur. Nitekim turizm sektöründe işletmelerin hayatlarını devam ettirebilmeleri ve karlılıklarını arttırabilmeleri tüketicilerin beklentilerini ve memnuniyetini gerçekleşmesiyle sağlanabilir (Öztürk ve Seyhan, 2005: 170).

Şarap turizminde, turizmin diğer alanlarında olduğu gibi, hizmet kalitesi müşteri memnuniyetinin bir önceliği haline gelmiştir. Buna karşılık, memnuniyetin tüketicinin satın alma sonrası algısını, gelecekteki satın alma kararını ve uzun vadeli müşteri sadakatini etkilediğine inanılmaktadır. Bu nedenle, hizmet kalitesinin mevcut bilincini ve şarap tadımının önemini anlamak esastır. Şarap turistinin ne talep ettiğini ne beklediğini ve motivasyonlarını anlamak, şarap turizmi endüstrisinde başarılı olmak isteyen işletmeler için hayati önem taşır (O'Neill ve Charters, 2000: 115). Ergüven ve diğerleri (2016) yılında yaptıkları çalışmada Trakya Bağ Rotası işletmelerinin dahil oldukları proje kapsamında artan taleple karşı karşıya kalacaklarını belirterek ihtiyaç duyulan insan kaynağından, tadım, sunum ve konaklama altyapısına kadar turistlerin bu taleplerini karşılamak gerektiğini vurgulamaktadır. Buradan yola çıarak işletmelerin bu talepleri karşılayıp karşılayamadıkları müşteri memnuniyeti açısından ölçülmeye çalışılacaktır. Bu nedenle çalışmada, Trakya Bağ Rotasında bulunan işletmelerin Servqual ölçeği ile ziyaretçilerin hizmet almadan önce beklentileri ve aldıktan sonra algıları arasındaki farkın saptanması amaçlanmaktadır. Böylece bağ işletmelerine yönelik, gelen ziyaretçilerin beklentilerini karşılaması amacıyla çeşitli yönetimsel öneriler geliştirilecektir.

\section{LITTERATÜR ARAŞTIRMASI}

\section{Şarap Turizmi ve Bağ İşletmeleri}

Günümüzde Şarap turizmi Dünya'da çokça rağbet gören bir turizm çeşidi olmuştur. Şarap turizmi, özellikle insanların şaraba olan merak ve ilgisi, şarap kültürünün, üretim sürecinin ve bölgesel çekiminin etkisiyle bir yerden bir yere seyahat etmelerine neden olmuştur (Carlsen ve Charters, 2006). Şarap turizminin değeri Avustralya başta olmak üzere birçok ülkede artarak 
gelişim göstermektedir. Ülkemizde ise durum biraz farklıdır. Türkiye, yaklaşık 6000 yıllık bir bağcllık kültürüne sahiptir. Bağcllık bu topraklarda yaşamış birçok toplumun geçim kaynağ olmuştur. International Organisation of Vine and Wine (OIV) raporuna göre ülkemiz sahip olduğu bağcılık yapılan topraklar açısından beşinci ve üzüm üretimi yapılan ülkeler arasında altıncı sırada yer almaktadır. Aynı rapora göre sofralık üzüm üretiminde ikinci sırada ve özellikle kuru üzüm üretimi ve ihracatında global pazarda ilk sırada yer almaktadır. Buna rağmen katma değeri daha yüksek ürün olan şarap üretiminde ve ihracatında ise Dünya ve $\mathrm{AB}$ oranlarının çok altında kalarak ortalama \%1-2 ihracat geliri elde etmektedir (OIV, 2019). Ancak ülkemiz Şili'yi örnek alarak şarabın tüketildiği bir ülke olmaktan ziyade şarabın üretildiği ve ihraç edildiği bir ülke konumuna geçebilecek kapasiteye sahiptir.

Şarap birçok ülkede turizm için önemli itici güç olarak karşımıza çıkmaktadır. Sadece şarabı iyi diye turistler tarafından tercih edilen bölgeler, şehirler ve ülkeler bulunmaktadır (Duran vd., 2019). Örneğin, nüfusu 150 bin bile olmayan Napa Vadisi, Kaliforniya bölgesinin Disneyland'dan sonra en çok turist çeken ikinci destinasyonudur. Bu bölgede şarap turizminin turistlere önemli bir deneyim yaşatacak kadar iyi bir şekilde pazarlandığını görmek mümkündür (Etyemez ve Özyılmaz, 2012; Albayrak, 2013).

Araştırmalar, şarap turizminin şaraphane operasyonlarının başarısı için gerekli olduğunu ve şarap imalathaneleri için bir dizi fayda sağlayabileceğini belirterek özellikle şarap turistlerinin şarap bölgesinin çekiciliğini aradıklarını söylemektedir (Brown ve Getz, 2005; Gross ve Brown, 2006). Brown ve diğerleri (2007), bir ürüne (şaraba) olan ilginin, ürünün üretildiği yere seyahat etme arzusu yaratma etkisine sahip olduğunu bulmuşlardır. Bu nedenle, bir şarap bölgesini ziyaret etmek, şarap üretimine katılmak, yemek kültürü ile etkileşim, yerel halk ve zevkli boş zaman etkinlikleri için motivasyon anlamına gelir. Araştırmacılar, şarap turizminin bir yaşam tarzı ürünü olduğu için, şarap imalathanesi ziyaretçilerinin bir şarap bölgesini ziyaret ettiklerinde doğal geziler, alışveriş ve diğer turistik yerleri ziyaret etme gibi bir dizi faaliyette bulunduklarını belirtmektedirler. Örneğin, ilk kez şarap imalathanesi ziyaretçileri daha çok öğrenme, deneyim ve şaraphane turlarına odaklanırken, tekrar şaraphane ziyaretçileri şarap tadımı ve şarap satın almaya odaklanır (Bruwer ve Alant, 2009). Nitekim Ergüven ve diğerleri (2016) creme de la creme turistlerinin boş zaman faaliyetlerini netleştirmek üzere yaptıkları araştırmalarında, Trakya Bağ Rotasındaki dokuz işletmeciyle görüşmüşlerdir. İşletmecilerle yapılan görüşmeler sonucunda ziyaretçilerin tamamının 'özel ilgi' çıkışlı olduğu ve işletme ziyaretçilerinin rekreatif faaliyetlerle ilgili olduğu sonucuna varılmıştır.

Şarap turistleri, ünlü şarap bölgelerinde üzüm bağlarını, şarap imalathanelerini ve şarap festivallerini organize turlarla veya tek başına ziyaret eden turistler olarak tanımlanmaktadır (Ahipaşaoğlu ve Korkmaz, 2008). Şarap turistlerine yönelik yapılan çalışmalar, şarap ile ilgili ve bilgili, para harcayan, maddi durumu iyi, eğitim seviyelerinin yüksek, orta ve üst yaş gurubu bireyler olduğu sonucuna varılmaktadır (Bako, 2016; Demirkol vd., 2016).

Şarap turistlerinin hizmet kalitesi hakkındaki algılarının belirlenmesi şarap imalathaneleri için önemlidir. Şarap turizminin yapısı gereği hizmet sektörü altında yer alması nedeniyle hizmet sektörü için geçerli olan koşullar şarap turizmi için de geçerlidir (Ahipaşaoğlu ve Korkmaz, 2008: 81). Başka bir deyişle, şarap turizmi çok yönlü bir deneyimdir. Bu nedenle hizmet kalitesi ölçeği, şarap işletmelerindeki yöneticiler tarafından çeşitli olguların hangi kalitede olduğu sonucuna ulaşmak için önemli bir araç olarak görülmektedir (Brochado vd., 2019: 16). Şarap turizminde, iş dinamiklerine uyum söz konusu olduğunda, sürekli iyileştirme sürecine göre ve turistlerin beklentilerini dikkate alan, kalitesi artan ürün ve hizmetler sunan işletmelerden bahsedilmektedir. Bu bağlamda, bir kişinin davranışını etkileyebilecek çeşitli faktörler (kültürel, sosyal, kişisel ve psikolojik) olduğundan, tüketiciyi tatmin etmek ve belli bir yere kadar hizmet kalitesini korumak büyük bir zorluktur. Hizmet sunumunun kalitesi turistlerin ihtiyaçlarını 
karşılamak için çok önemlidir (Freitas vd., 2017: 342). Şaraphanelerde turizm işletmelerine benzer şekilde turistlerin hizmet kalitesi konusundaki ilk algıları hizmet kalitesi beklentilerini aştıysa, şaraphanenin kaliteli hizmet sunduğu kabul edilir; tersine, turistlerin hizmet kalitesiyle ilgili beklentileri, hizmet kalitesi konusundaki ilk algılarını aşarsa, şaraphanenin düşük kaliteli hizmet verdiği kabul edilmektedir (Jinling, 2007: 258). Şarap turistleriyle ilgili Bako'nun (2016) yaptığı çalışmada; Şarap turistlerinin Kula ile ilgili şarap turizmi deneyimi öncesinde beklentilerin düşük olduğu ve Kula'nın beklentileri karşılamayacak düzeyde olduğuna yönelik yerleşmiş bir alg1 olduğu ifade edilmektedir. Ancak şarap turistlerinin deneyim sonralarında beklentilerinin çok üstünde hizmet ve ürün kalitesi aldıklarını belirttikleri ifade edilmektedir.

\section{Hizmet Kalitesi ve Servqual Hizmet Kalitesi Ölçeği}

Hizmet kalitesinin tanımlanmasına ilişkin yapılan çalışmalarda ortaya konan tanımlar, bazı yönlerden benzerlik gösterse de bu kavramın kabul edilmiş ortak bir tanımı üzerinde hala uzlaşılamamıştır (Puri ve Singh, 2018: 745). Hizmet kalitesi üzerine yapılan ilk çalışmalardan birinde Parasuraman vd., (1985), “Müşteri tarafından algılandığı şekliyle hizmet kalitesi, müşteri hizmet algıları ve beklentileri arasındaki tutarsızlığın derecesi ve yönü" şeklinde bir tanımlama yapmıştır. Zeithaml (1988) 'e göre, hizmet kalitesi bir hizmetin mükemmelliği olarak tanımlanır ve yine de "algılanan hizmet kalitesini", bir işletmenin büyük ölçüde değerinin bir alıcı tarafından değerlendirilmesi olarak tasvir etmeye devam eder. Eshghi vd., (2008), hizmet kalitesini bir hizmetin müşteri tarafından genel ölçümü olarak tanımlamıştır. Ghylin vd., (2008), hizmet kalitesinde firmaların üstün kalite düzeyinde hizmet sunma konusunda yetkin olacaklarını ve bunun da müşteri memnuniyetini artıracağını belirtmiştir.

Hizmet kalitesi anlayışı ve kaliteyi etkileyen faktörler arasında hizmet veren işletmelerde çalışanların görevi ve becerilerinin gruplandırılması, işletmelerin performans mükemmelliği ve çalışanların davranışları gibi tutumlar yer almaktadır. Ayrıca, çalışanların müşterilerin ihtiyaçlarına uygun tatmin edici bir şekilde ve müşterilerin beklentileri doğrultusunda hizmet vermeleri hizmet kalitesi unsurları arasında sayılmaktadır (Budianto, 2019: 300). Tipik olarak hizmetler, tüketim sürecinde yüksek tüketici katılımı gerektiren ürünlerdir. Verilen bir hizmetin algılanan kalitesinin, tüketicinin beklentilerini aldığı hizmetle karşılaştırdığı, yani algılanan hizmeti ortaya koyduğu bir değerlendirme sürecinin sonucunun, beklenen hizmete karşı olacağını söylemek mantıklıdır. Bu sürecin sonucu, hizmetin algılanan kalitesi olacaktır. Dolayısıyla, hizmetin kalitesi, beklenen hizmet ve algılanan hizmet şeklinde iki değişkene bağlıdır (Grönroos, 1984:37).

Turizm endüstrisi yüksek rekabet ile karakterize edilmektedir. Bu nedenle hizmet kalitesinin pazarda sürdürülebilir bir rekabet avantajı elde etmenin temel unsurlarından biri olduğu kanıtlanmıştır. Kalite, müşterilerin gereksinimlerinin yanı sıra belirtilen ve belirtilmeyen ihtiyaçlarının karşılanması olarak kabul edilir (Igreja vd., 2020: 43).

Hizmet kalitesi, tüketicilerin hizmet performansına ilişkin beklentileri ile aldıkları hizmete ilişkin algıları arasındaki ayrımdır (Kusonwattana ve Liangrokapart, 2020: 848). Hizmet iyileştirmeleri genellikle hizmet standartlarının oluşturulmasını ve hizmet kalitesinin ölçülmesini zorunlu kılar. Bununla birlikte, hizmet kalitesinin soyut ve anlaşılmaz doğası nedeniyle hizmet kalitesinin ölçülmesi kolay bir iş değildir (Min ve Min, 1997: 582). Turizm sektöründe olduğu gibi diğer işletmelerde de hizmet kalitesinin ölçümü değerlidir. Bundan dolayı ölçülemeyen unsurun geliştirilip, yönetilmesi mümkün olmayabilir (Küçükaltan vd., 2017). İşletmelerde müşterilerin devamlılığını ve satın alma davranışlarını kalite yüksek düzeyde etkilediğinden dolayı hizmet kalitesinin ölçülmesi gerekmektedir (Altan ve Atan, 2004: 20). Bu kapsamda 1985 yılında Parasuraman, Zeithaml ve Berry tarafından, hizmet kalitesini ölçmek için en başarılı araçlardan 
biri olarak bilinen SERVQUAL modeli geliştirilmiştir. Çok boyutlu bir model olan Servqual, müşterilerin algıları ve beklentileri arasındaki farkı ortaya koyan bir ölçektir (Shafiq vd., 2019: 63). Parasuraman ve arkadaşları tarafından geliştirilen ölçekte 10 boyut elde edilmiştir. Daha sonra bazı boyutların kendi aralarında ilişkili olması sebebiyle boyutlar birleştirilerek beş boyut ortaya konmuştur. Bu boyutlar "fiziksel özellikler, güvenirlik, heveslilik, güvence ve empati" olarak adlandırılmıştır (Cronin ve Taylor, 1992: 58).

Fiziksel Özellikler fiziksel tesislerin, ekipmanın, çalışanların kişisel görünümlerini ve malzemenin görünümü biçiminde somut unsurları tanımlar (Saadillah ve Syairudin: 2019: 105). Güvenilirlik, vaat edilen hizmetlerin sunulmasındaki doğruluk olarak yorumlanabilir. Örneğin, bir çalışan söz verildiği gibi hizmet sunabiliyorsa ve tüketicilerin karşılaştı̆̆ çözülmesine yardımcı olabiliyorsa, işletmenin güvenilir olduğu söylenir (Saadillah ve Syairudin: 2019: 105; Wang vd., 2015: 34). Heveslilik, hizmet sağlayıcıların tüketicilere yardım etme ve hizmetleri hızlı bir şekilde sunma istekliliğidir (Fettahlığlu vd., 2016: 851). Müşterilere hızlı hizmet verebilmek için içtenlikle çaba göstermektir. (Kusonwattana ve Liangrokapart, 2020: 848). Güvence bilgi, nezaket ve çalışanın tüketicileri ikna etme ve onlara güven verme yeteneğidir. Şirketin, çalışanların her zaman kibar olabilmeleri, müşteri sorunlarını çözme becerisine sahip olmaları, sunulan ürünler veya hizmetler hakkında iyi bilgi sahibi olmalarıdır (Filiz vd., 2010: 64). Empati, işletmenin kendisini müşterinin yerine koyması, her müşteriye ayrı özel ilgi göstermesi olarak tanımlanabilir (Rahman, 2007: 41). Hizmet kalitesi ölçümü sonucunda üç durum ortaya çıkar; (1) Beklenen hizmetin algılanan hizmetten büyük olması durumunda kalite düşük olarak kabul edilir. (2) Beklenen hizmetin algılanan hizmete eşit olması durumunda tatmin edici bir kalite düzeyine ulaşılır. (3) Beklenen hizmetin algılanan hizmetten düşük olması durumunda ise üstün kalite gerçekleşmiş demektir (Filiz, 2011: 39). Buna göre beklenen hizmet ve algı arasındaki boşluk belirlenerek işletmelerin bu boşluklara göre önlem alması yerinde olacaktır.

\section{Bağ İşletmelerinin Hizmet Kalitesi Ölçümü}

Servqual ölçeği, hizmet sektöründe ve özellikle turizm sektöründe yer alan çekirdek hizmetlerin sunulduğu ulaştırma hizmetlerinden (Chou vd., 2011; Pakdil ve Aydın, 2007) yiyecek içecek hizmetlerine (Alroub vd., 2012; Aksu vd., 2016; Bilgin ve Kethüda, 2017), konaklama hizmetlerinden (Chaturvedi, 2017; Shafiq vd., 2019) eğlence hizmetlerine (Albattat ve Romli, 2017; Šíma vd., 2020) kadar pek çok alanda müşteri tatminini ölçmek için uzun süredir kullanılmaktadır. Şarap, bir yaşam tarzı içeceği olarak kabul edilir ve şarap tüketicisinin bununla olan ilişkisi, yiyecek ve konaklamada olduğu gibi, doğuştan gelen bir ihtiyaca değil, edinilmiş bir ihtiyaca dayanır (Bruwer ve Alant, 2009). Ancak birçok özellik açısından yiyecek içecek sektörüne yakın olan şarap turizmi için diğer sektörlerde olduğu gibi yönetimin müşterilerin ne istediğini ve ne beklediğini doğru algılayıp algılayamayacağı önemlidir. Beklentiler, tüketicinin hizmet kalitesi değerlendirmelerinin ve memnuniyetinin ana belirleyicisi olarak öne çıkar. Hizmetleri verdikten sonra, hizmet sağlayıcılar müşterilerin beklentilerinin ne kadar karşılandı̆̆ını izlemelidir (Pakdil ve Aydın, 2007). Şarap tüketiminin kendisi, bazı insanlar için bir deneyim hazzı olarak görülebilir ve sayısız deneyimler bağlamında kişisel eğlenceyi (ister basit bir şarap içicisi ister bir uzman olsun) hedefleyen duyusal ve zevkli bir aktivite olarak karşımıza çıkar. Bu kapsamda şarap turizmi faaliyeti, şarap imalathaneleri, şarap bölgesi ve ziyaretçi-tüketici arasındaki karmaşık ilişkinin bir uzantısıdır (Bruwer ve Alant, 2009: 235). Bu nedenle hizmet kalitesinin dolayısıyla müşteri memnuniyetinin ölçülmesi de karmaşık olabilmektedir.

Şarap turizmi nispeten genç bir turizm sektörüdür ve böylesine iyimser büyüme ve beklentilere rağmen, sürdürülebilirliğini ve uzun vadeli kârlılı̆̆ını olumsuz etkileme potansiyeline sahip bir dizi kritik kalkınma sorunuyla karşı karşıyadır. Böyle bir sorun, bağlarda yaşanan hizmet 
kalitesini düşürerek tüketicinin memnuniyetini, gelecekteki satın alma niyetini ve marka sadakati üzerindeki etkisini zayıflatacaktır. Şarap turizminin artan önemi ve bu sektörün artan rekabet gücü, üreticiler ve tüketiciler tarafından sunulan hizmetlerin kalitesine yönelik endişelerin artmasına da neden olmaktadır ( $\mathrm{O}^{\prime}$ Neill ve Chartes, 2000: 112). Bu nedenle bağ işletmelerinde çalışanların hizmet kalitesi konusunda donanımlı olmaları ve bunu eğitimlerle sürekli olarak geliştirmeleri işletmelerin rekabet gücünü artırabilecektir. Böylece şarap turizmine yönelik hizmet sunan işletmelerin sundukları yüksek hizmet kalitesi sürdürülebilir olmalarını sağlayacaktır.

Şarap turizminde hizmet kalitesinin ölçümüne yönelik yapılan bir çalışmada personelin samimiyeti, nezaketi, genel hizmeti ve bilgisinin şaraphanede şarap satın alma veya almama kararını etkilediğini ortaya koymaktadır. Bununla birlikte hizmet veren personelin tutumu, empati ve ilgisi gibi hizmet kalitesinin somut olmayan boyutunun, tüketicinin satın alma kararını şarap kalitesinden daha fazla etkilediği görülmüştür (Lee vd., 2016: 2986). Öte yandan, diğerleri (Bruwer ve Kelley (2015) çalışmalarında şarap tadım odalarında müşterilerin hizmet performans algıları ile memnuniyet arasındaki ilişkiyi karşılaştırdıklarında aralarında güçlü bir ilişki bulunmadığı ortaya çıkmıştır. Lee ve diğerleri (2016), çalışmalarında Çinli şarap turistlerin memnuniyetini ve sadakatini etkileyen hizmet faktörlerin bileşenleri araştırıldığında şarap tadım operasyonlarının ve tadına bakılan şarapların kalitesinin yanı sıra personelin tutumunun da önemli olduğunu belirtmiştir (Ertürk, 2011; Bayat ve Polat, 2019: 563). Igreja vd., (2020), Hotel Torre Gomariz Wine \& Spa'da yaptıkları keşifsel çalışmaları sonucunda otel misafirlerinin algı ve beklentileri arasında farklılıklar olduğu sonucuna ulaşmıştır. Özellikle, gelecekte deneysel olarak test edilmesi için kavramsal bir model önermektedirler. Haverila vd., (2020), SERVQUAL modelini kullanarak şarap tadım odaları bağlamında memnun ve memnun olmayan müşterileri karşılaştırmak ve müşteri ihtiyaçlarını daha iyi anlamak için modeldeki ilişkileri hizmet deneyimi açısından araştırarak hizmet kalitesi boyutlarından sadece güvenirlik boyutunun dışındaki diğer boyutlar tarafından müşteri memnuniyeti ile önemli ölçüde ilişkili olduğunu ortaya koymuşlardır.

Ahipaşaoglu ve Korkmaz (2008), şarap turistlerinin şarap tadımına yönelik hizmet kalitesine ilişkin algıları SERVQUAL ölçeği ile araştırarak turistlerin hizmet kalitesi ile ilgili algıları ile şarap tadım deneyimi arasında önemli bir fark ortaya çıkmadığını görmüşlerdir. Ayrıca turistlerin demografik değişkenleri ile hizmet kalitesi algıları arasında bazı ilişkiler ve farklılıklar olduğu belirlenmiştir. O' Neill vd., (2002) araştırmalarında, Avustralya şarap turizmi endüstrisindeki önem performans tekniğinin bir uygulaması yoluyla hizmet kalitesi yapısının kavramsallaştırılması ve ölçülmesini ve bunun davranışsal niyetle ilişkisini incelemişlerdir. Etkili bir mahzen veya çeşitli şaraplar, daha düşük satışlar sağlayabilir, ancak empati ve duyarlılık gibi faktörlere vurgu yaparak, bu unsurların uzun vadede şaraphaneye çok daha fazla kazanç sağlayan çok güçlü bir marka olanağı yaratacağını belirtmektedirler.

Jinling (2007), araştırmasında Tayvan şarap işletmesinin turistlerin memnuniyetini etkileyen odak özelliklerini ortaya çıkarmak ve müşteri beklentisi ile hizmet kalitesine yönelik algı arasındaki farklılığı araştırmak üzere yaptığı çalışmada, turistlerin görsel olarak çekici ve somut malzemelere kıyasla bağ işletmesindeki personelin profesyonel ve nazik tavrına daha fazla önem verdiğini göstermektedir. Müşterilerin en yüksek beklentileri sırasıyla güvence, empati, güvenirlik ve fiziksel özellikler olduğu ortaya çıkmıştır.

Tüm bu çalışmalara dayanarak diğerleri "Bağ işletmelerine yönelik beklenen ve algılanan hizmet düzeyleri arasında anlamlı fark var mıdır" sorusundan yola çıkarak aşağıdaki hipotezler test edilmektedir. 
H1: Trakya Bağ Rotasında yer alan bağ işletmelerinin sahip olduğu fiziksel özellik ve çalışanlarının hevesliliği açısından, işletmeleri ziyaret eden turistlerin bekledikleri hizmet kalitesi ile algıladıkları hizmet kalitesi arasında farklılık vardır.

H2: Trakya Bağ Rotasında yer alan bağ işletmelerinde çalışanların kurduğu empati ve güvenirlik açısından, işletmeleri ziyaret eden turistlerin bekledikleri hizmet kalitesi ile algıladıkları hizmet kalitesi arasında farklılık vardır.

H3: Trakya Bağ Rotasında yer alan bağ işletmelerindeki işletmelere duyulan güven bakımından, işletmeleri ziyaret eden turistlerin bekledikleri hizmet kalitesi ile algıladıkları hizmet kalitesi arasında farklılık vardır.

\section{YÖNTEM}

Bu bölümde araştırmanın amacına bağlı olarak belirlenen yöntem doğrultusunda gerçekleştirilen analizlere yer verilmiştir. Bununla birlikte çalışma alanı, veri toplama teknikleri, örnekleme yöntemi ve örneklem büyüklügü ile verileri elde etmek için kullanılan ölçeklere yer verilmiştir.

\section{Çalışma Alanı}

Trakya Bağ Rotası, Trakya Turizm İşletmecileri Derneği aracıllğıyla bölgede etkinlik gösteren 12 bağ işletmesinin işbirliği ile meydana gelen ülkemizdeki ilk bağ rotası projesidir (Ömür, 2016). Trakya Kalkınma Ajansının finansal desteği ile hayata geçirilen Trakya Bağ Rotası projesi sadece bölge açısından değil diğer bölgelerdeki şarap üreticileri için de önemli bir örnek teşkil etmektedir. Trakya Kalkınma Ajansının 2013-2023 yılları için bölgedeki tüm paydaşlarla birlikte hazırlamış olduğu kapsamlı Master Planında, şarap turizmine geniş yer verilmiştir. Paydaşların bölge için önerdiği alternatif turizm türlerinden biri katma değeri yüksek olan şarap turizmidir. Bu kapsamda paydaşlar tarafından bir de proje önerilmiş ve Trakya Kalkınma Ajansı projeyi hibelendirerek 2013 yılında hayata geçirmiştir. Bu projeyle birlikte bölgede şarap turizmiyle ilgilenen, eğitim düzeyi ve gelir seviyesi yüksek ziyaretçi profiline sahip katma değeri yüksek bir turist profilinin oluşması sağlanmıştır. Böylece mevcut turizm potansiyelinin bölgede hareketlenmesi ve gelişmesi mümkün olabilmektedir (Salha ve Cinnioğlu 2018: 644). Ayrıca, ziyaretçilerin turlarla veya kendi araçlarıyla günü birlik veya konaklayabilecekleri önemli bir girişim olarak bölgede bir yatırım potansiyeli oluşmuştur (Akdağ, 2015:5). Bağ rotasının yapısı gereği ziyaretler genellikle birden fazla işletmeye yapılmakta ve kişilerin genel olarak bir fikri oluşmaktadır.

\section{Veri Toplama}

Bu çalışmada, Trakya Bağ Rotası'nda faaliyet gösteren bağ işletmelerinin müşterilerine sunmuş olduğu hizmet kalitesinin tespit edilmesi amaçlanmaktadır. Ayrıca turistlerin profillerinin belirlenmesi, işletmelerin talebi karşılayabilmeleri ve kaliteli hizmet sunabilmelerine ve onların istek ve arzularının tespit edilmesine yardımcı olacaktır. Müşterilerin memnuniyet düzeyi, sunulan hizmetin kalitesine bağlı olmakla birlikte, işletmelerin başarısı için de çok önemli bir faktördür. Bundan dolayı uluslararası literatürde kabul görmüş SERVQUAL ölçeği kullanılarak, şarap üretimi ve tüketimi yapılan bağlarda, müşterilerin bekledikleri hizmet kalitesi ile deneyimledikleri hizmet kalitesi arasında fark olup olmadığının belirlenmesi amaçlanmıştır. Bu ölçeğin içerdiği kalitenin beş boyutu güvenirlik, heveslilik, güvence, empati ve fiziksel özelliklerdir. Anketteki sorular hazırlanırken hizmet kalitesinin ölçümü için Parasuraman vd., 
(1988)'nin geliştirdiği Servqual ölçeğinden yararlanılmış, ayrıca araştırmanın amacı doğrultusunda ölçeğe bazı ilaveler de yapılmıştır.

Araştırmanın evrenini Tekirdağ, Şarköy, Gelibolu ve Kırklareli destinasyonlarında yer alan bağ işletmelerine gelen turistler oluşturmaktadır. Trakya Bağ Rotasındaki işletmelere gelen misafirlere hem yüz yüze hem de sosyal medya üzerinden iletişime geçip tesadüfi olmayan örnekleme yöntemlerinden kolayda örnekleme yöntemi ile anket uygulanmıştır. Elde edilen 310 anketten bir kısmı eksik veya hatalı doldurmadan dolayı veri setinden çıkarılmıştır. Geri kalan 276 anket çalışma için yeterli görülmüş ve veri analizine geçilmiştir. Anketler 2019 yılı boyunca, özellikle bağ bozumunun olduğu Ağustos-Eylül-Ekim aylarında yüz yüze, diğer aylarda ise oluşturulan internet linkinin, sosyal medyada yer alan şarap turizmiyle ilgili platformlar ve şarap turizmine özel ilgi gösteren ve bağları ziyaret ettiği tespit edilen instagram kullanıcılarına gönderilmesiyle toplanmıştır. Soru formu 3 bölümden oluşmaktadır. Birinci bölüm soruları turistlerin demografik bilgilerini belirlemeye yöneliktir. İkinci bölüm 5’li Likert ölçeğine göre hazırlanmış ve turistlerin beklentilerine yönelik ifadeleri içermektedir. Üçüncü bölüm benzer şekilde 5'li Likert ölçeğine göre hazırlanmış ve turistlerin algılarını tespit etmeye yöneliktir. Ayrıca hazırlanan anket formu uzman görüşleri alınmak üzere üç doktor öğretim üyesine sunulup, görüşleri alınıp uygun formata getirilmiştir. Araştırma verilerinin analizinde, SPSS 22.0 istatistik paket programı kullanılarak güvenilirlik, geçerlilik, farklılık ve ilişki analizleri yapılmıştır.

\section{BULGULAR}

Araştırma kapsamında yer alan kişilerin yaş dağılımları, cinsiyetleri, eğitim durumları, medeni durumları, aylık gelirleri ve gelmelerindeki amaca yönelik demografik özelliklerini tespit etmek üzere sorulan sorulardan elde edilen bulgular Tablo 1'de sunulmuştur.

Tablo 1. Araştırmaya Katılan Turistlere Ait Genel Bilgiler

\begin{tabular}{|c|c|c|c|c|c|c|c|c|}
\hline Yaş & f & $\%$ & $\begin{array}{l}\text { Medeni } \\
\text { Durum }\end{array}$ & f & $\%$ & Cinsiyet & $\mathbf{f}$ & $\%$ \\
\hline $18-25$ & 29 & 10.5 & Bekar & 152 & 55.5 & Erkek & 115 & 41,7 \\
\hline $26-35$ & 138 & 50.0 & Evli & 121 & 44.2 & Kadın & 161 & 58,3 \\
\hline $36-45$ & 74 & 26.8 & Eğitim & $f$ & $\%$ & Gelmenizdeki Amaç & $\mathbf{f}$ & $\%$ \\
\hline $46-55$ & 22 & 8.0 & İlköğretim & 2 & .7 & Şarap & 185 & 67.0 \\
\hline 56 ve üzeri & 13 & 4.7 & Ortaokul & 2 & .7 & Konaklama & 4 & 1.4 \\
\hline Gelir Düzeyi & $f$ & $\%$ & Lise & 10 & 3.6 & Yeme-İçme & 12 & 4.3 \\
\hline 1000 ve alt1 & 58 & 21.0 & Ön Lisans & 23 & 8.3 & Alışveriş & 1 & .4 \\
\hline $1001-3000$ & 22 & 8.0 & Lisans & 136 & 49.3 & Doğal Çekicilikler & 34 & 12.3 \\
\hline $3001-5000$ & 57 & 20.7 & \multirow{3}{*}{ Lisansüstü } & \multirow{3}{*}{101} & \multirow{3}{*}{36.6} & Kültür Çekicilikler & 9 & 3.3 \\
\hline $5001-7000$ & 54 & 19.6 & & & & $\begin{array}{l}\text { Arkadaşlarımla } \\
\text { Birlikte Olmak }\end{array}$ & 25 & 9.1 \\
\hline 7001 ve üzeri & 85 & 30.8 & & & & Diğer & 6 & 2.2 \\
\hline $\begin{array}{l}\text { Bağ } \\
\text { gezintisinden } \\
\text { memnun } \\
\text { kaldım }\end{array}$ & f & $\%$ & & & & $\begin{array}{l}\text { Bağ rotası } \\
\text { ziyaretinde } \\
\text { problemler yaşadım }\end{array}$ & $\mathbf{f}$ & $\%$ \\
\hline Evet & 241 & 87.3 & & & & Evet & 16 & 5.8 \\
\hline Hayır & 21 & 7.6 & & & & Hayır & 222 & 80.4 \\
\hline
\end{tabular}


Elde edilen bulgulara göre araştırmaya katılanlarda en fazla yığılmanın 26-35 (\%50) yaş aralığında, en düşük yığılmanın ise 56 ve üzeri (\%4.7) yaş aralığında olduğu tespit edilmiştir. Katılımcların \%41.7'sini erkekler, \%58.3'ünü kadınlar oluşturmaktadır. Eğitim düzeylerine bakıldığında \%7'sini ilköğretim, \%7'sini ortaokul \%3,6'sını lise, \%8,3'ünü ön lisans, \%49.3'ünü lisans ve \%36.6'nın lisansüstü düzeyinde eğitim aldıkları görülmüştür. Medeni durumda ise, katılımcların \%55.5'i bekar, \%44.2' si evlidir. Aylık gelir dağılımında ise, \%21.0'ın $1000 \mathrm{TL}$ altında, \%8.0'in 1001-3000 TL, \%20.7'si 3001-5000 TL, \%19.6's1 5001-7000 TL ve son olarak \%30.8'in 7001 TL ve üzeri bir gelir elde ettikleri tespit edilmiştir. Turistlerin bağları ziyaret amaçları ise çoğunlukla (\%67.0) Şarap'ı tercih etmekleri olarak belirtilmiştir. Ziyaretçilerin bağ gezintisinden \%87.3'ü memnun kalmıştır. Bağ rotası ziyaretinde \%80.4 ile problem yaşanmamıştır.

Tablo 2. Beklenti Düzeyi Faktör Analizi

\begin{tabular}{|c|c|c|c|}
\hline Fiziksel Özellikler ve Heveslilik & $\begin{array}{l}\text { Faktör } \\
\text { Yükü }\end{array}$ & $\begin{array}{l}\text { Açıklanan } \\
\text { varyans } \\
\text { değeri } \\
\end{array}$ & $\begin{array}{l}\text { Cronbach } \\
\text { Alfa Değeri }\end{array}$ \\
\hline B_1Çalışanlar özenle giyinmiş. & 0.770 & \multirow{9}{*}{36.034} & \multirow{9}{*}{0.948} \\
\hline B_2Personel işinde daha profesyonel. & 0.825 & & \\
\hline $\begin{array}{l}\text { B_3Çalışanlar yardım etmek için daha } \\
\text { istekli. }\end{array}$ & 0.818 & & \\
\hline B_4.Daha hizlı hizmet verirler. & 0.787 & & \\
\hline B_5.Çalışanlar kibar ve nazikler. & 0.723 & & \\
\hline B_6.Çalışanlar şarap hakkında bilgililer. & 0.769 & & \\
\hline $\begin{array}{l}\text { B_7.Çalışanlar kişisel ilgi ve özen } \\
\text { gösterebilir. }\end{array}$ & 0.781 & & \\
\hline $\begin{array}{l}\text { B_8.Şarap içecekleri uygun bir şekilde servis } \\
\text { edilir. }\end{array}$ & 0.695 & & \\
\hline B_9.Personelin kıyafetleri temiz olması. & 0.655 & & \\
\hline Empati ve Güvenirlik & $\begin{array}{l}\text { Faktör } \\
\text { Yükü }\end{array}$ & $\begin{array}{l}\text { Açılkanan } \\
\text { varyans } \\
\text { değeri }\end{array}$ & $\begin{array}{l}\text { Cronbach } \\
\text { Alfa Değeri }\end{array}$ \\
\hline $\begin{array}{l}\text { B_15.Servisin ne zaman yapılacağı hakkında } \\
\text { bilgi verebilirler. }\end{array}$ & 0.777 & \multirow[t]{4}{*}{18.966} & \multirow[t]{4}{*}{0.832} \\
\hline $\begin{array}{l}\text { B_16.Çalışanlar çok özel ihtiyacımı } \\
\text { anlayabilirler. }\end{array}$ & 0.633 & & \\
\hline $\begin{array}{l}\text { B_17.Mevcut şarap içeceklerin çeşitliliği } \\
\text { geniş olabilir. }\end{array}$ & 0.741 & & \\
\hline B_18.Tatma süreleri uygun olabilir. & 0.663 & & \\
\hline Güvence & $\begin{array}{l}\text { Faktör } \\
\text { Yükü }\end{array}$ & $\begin{array}{l}\text { Açıklanan } \\
\text { varyans } \\
\text { değeri }\end{array}$ & $\begin{array}{l}\text { Cronbach } \\
\text { Alfa Değeri }\end{array}$ \\
\hline B_11.Şarap içeceği lezzetli olabilir. & 0.687 & \multirow{3}{*}{17.174} & \multirow{3}{*}{0.857} \\
\hline $\begin{array}{l}\text { B_12.Servis edilen şarap içeceği aromalı } \\
\text { olabilir. }\end{array}$ & 0.815 & & \\
\hline $\begin{array}{l}\text { B_13.Şarap içeceklerin tat kalitesi yüksek } \\
\text { olabilir. }\end{array}$ & 0.787 & & \\
\hline
\end{tabular}


Çalışmada çok sayıdaki ifadeyi daha az sayıda, anlamlı ve birbirinden bağımsız faktörler haline getirmek amacıyla açımlayıcı faktör analizi uygulanmıştır. Analiz sonucunda boyutlar toplam varyansın \%72'sini açıklamaktadır. Verilerin faktör analizine uygunluğunu sınamak amacıyla Kaiser-Meyer-Olkin (KMO) ve Barlett küresellik testi uygulanmıştır. Kaiser-Meyer-Olkin (KMO) değeri 0.94 'dür. Verilerin yapılan teste uygunluğunu ölçmek için yapılan KMO ve Barlett testi sonucu istatiksel olarak anlamlı bulunmuştur $(\mathrm{p}=0.000<0.05)$ ve faktör analizine tabi tutulan değişkenler arasında ilişki olduğu tespit edilmiştir. Gerçekleştirilen faktör analizi sonucunda, hizmet kalitesini ölçmeye ilişkin ifadeler Servqual hizmet kalitesi ölçüm modelinden farklı olarak beş faktör yerine 3 faktör altında toplanmıştır. Bu araştırmada faktör analizi sonucunda fiziksel özellikler ve heveslilik, empati ve güvenirlik boyutlarına ait ifadelerin aynı faktör altında toplandığı görülmektedir.

Yapılan güvenirlik analizi sonucunda restoranlarda beklenen hizmet kalitesi ölçeğinin Cronbach's Alpha katsayısı 0.929 bulunmuştur. Ayrıca, Fiziksel özellikler ve Heveslilik boyutu $(0,885)$, Empati ve Güvenirlik (0.832), ve Güvence $(0.857)$ alt ölçeklerinin güvenirlik katsayıları hesaplanmıştır. Bulunan sonuçlara göre ölçeklerin yüksek derecede güvenilir olduğu söylenebilmektedir (Tablo 2).

Tablo 3. Algı Düzeyi Faktör Analizi

\begin{tabular}{|c|c|c|c|}
\hline Fiziksel Özellikler ve Heveslilik & Faktör Yükü & $\begin{array}{l}\text { Açılanan } \\
\text { varyans }\end{array}$ & $\begin{array}{l}\text { Cronbach } \\
\text { Alfa }\end{array}$ \\
\hline A_1.Çalışanlar özenle giyinmişti. & 0.748 & \multirow{9}{*}{32.148} & \multirow{9}{*}{0.928} \\
\hline A_2.Personel işinde profesyoneldi. & 0.797 & & \\
\hline A_3.Çalışanlar yardım etmek için istekliydi. & 0.777 & & \\
\hline A_4.Hızlı hizmet veriyorlardı. & 0.704 & & \\
\hline $\begin{array}{llll}\text { A_5.Çalışanlar } & \text { kibar } & \text { ve } & \text { nazik } \\
\text { davranmıslardı. } & & & \\
\end{array}$ & 0.776 & & \\
\hline A_6.Çalışanlar şarap hakkında bilgiliydiler. & 0.702 & & \\
\hline A_7.Çalışanlar kişisel ilgi ve özen gösterdi. & 0.645 & & \\
\hline $\begin{array}{l}\text { A_8.Şarap içecekleri uygun bir şekilde servis } \\
\text { edildi. }\end{array}$ & 0.645 & & \\
\hline A_9.Personelin kiyafetleri temizdi. & 0.636 & & \\
\hline Empati ve Güvenirlik & Faktör Yükü & $\begin{array}{l}\text { Açıklanan } \\
\text { varyans }\end{array}$ & $\begin{array}{l}\text { Cronbach } \\
\text { Alfa }\end{array}$ \\
\hline $\begin{array}{l}\text { A_15.Servisin ne zaman yapılacağı hakkında } \\
\text { bilgi verdiler. }\end{array}$ & 0.794 & \multirow[t]{4}{*}{18.610} & \multirow[t]{4}{*}{0.829} \\
\hline A_16.Çalışanlar çok özel ihtiyacımı anladı. & 0.740 & & \\
\hline $\begin{array}{l}\text { A_17.Mevcut şarap içeceklerin çeşitliliği } \\
\text { genişti. }\end{array}$ & 0.635 & & \\
\hline A_18.Tatma süreleri uygundu. & 0.696 & & \\
\hline Güvence & Faktör Yükü & $\begin{array}{l}\text { Açıllanan } \\
\text { varyans }\end{array}$ & $\begin{array}{l}\text { Cronbach } \\
\text { Alfa }\end{array}$ \\
\hline A_11.Şarap içeceği lezzetliydi & 0.758 & \multirow{3}{*}{16.424} & \multirow{3}{*}{0.807} \\
\hline A_12.Servis edilen şarap içeceği aromalıydı. & 0.753 & & \\
\hline A_13.Şarap içeceklerin tat kalitesi yüksekti. & 0.783 & & \\
\hline
\end{tabular}


Algı düzeyi faktör analizi için yapılan analiz doğrultusunda elde edilen sonuçlar Tablo 3 'te verilmiştir. Analiz sonucunda 16 madde ve 3 faktör elde edilmiştir. Faktör analizi sonuçları toplam varyansın \%67'sini açıklamaktadır. Kaiser-Meyer-Olkin (KMO) değeri 0.93 'tür. Verilerin yapılan teste uygunluğunu ölçmek için yapılan KMO ve Barlett testi sonucu istatiksel olarak anlamlı bulunmuştur $(\mathrm{p}=0.000<0.05)$ ve faktör analizine tabi tutulan değişkenler arasında ilişki olduğu tespit edilmiştir. Yapılan güvenirlik analizi sonucunda restoranlarda beklenen hizmet kalitesi ölçeğinin Cronbach's Alpha güvenilirlik katsayısı 0.939 bulunmuştur. Ayrıca, Fiziksel özellikler ve Heveslilik boyutu (0.928), Empati ve Güvenirlik (0.829), ve Güvence (0.807) alt ölçeklerinin güvenirlik katsayıları hesaplanmıştır. Bulunan sonuçlara göre ölçeklerin yüksek derecede güvenilir olduğu söylenebilmektedir (Tablo 3).

\section{SERVQUAL Ölçeği ile Hizmet Kalitesinin Belirlenmesi}

Şarap işletmelerinde hizmet kalitesinin belirlenmesi için Servqual ölçeği uygulanmış ve elde edilen veriler Tablo 4 'te sunulmuştur.

Fiziksel Özellikler ve Heveslilik Boyutu: Bu boyutta algılanan hizmet kalitesinde 'Çalışanların kibar ve nazik olması' (4.3116) ve 'Personel kıyafetlerinin temiz olması' (4.3116) öne çıkan ifadelerdir. Beklenen hizmet kalitesinde ise, 'İçeceklerin uygun bir şekilde servis edilmesi' ve 'Personel kıyafetlerinin temiz olması' (4.3587) ön plana çımaktadır. Bu boyutta sadece 'Çalışanlar kibar ve nazik olması' sorusuna verilen cevaplar 0.0036 ile beklentilerin üzerinde gerçekleşmiştir. Diğer önermelerin hepsi ise negatif yönlüdür. En az memnuniyet duyulan 0.148 ile 'Daha hızlı hizmet verirler' önermesidir. Bağ işletmelerin fiziksel özellikler ve heveslilik için beklenti ve algı ortalamaları ile hesaplanan servqual skoru -0.1566 olarak bulunmuştur. Bu sonuca göre, bağ işletmelerinin fiziksel özelliklerinin ve çalışanların hevesliliği müşterilerin beklentilerini karşılayamamaktadır.

Empati ve Güvenirlik Boyutu: Tüm sorulara verilen yanıtlara bakıldığında müşteri beklentilerinin deneyimledikleri hizmet kalitesinin üzerinde gerçekleştiği görülmektedir. Sonuca göre bu boyutta müşteri memnuniyeti sağlanamamıştır. Algılanan hizmet kalitesi ifadelerinden 'Mevcut şarap içeceklerinin çeşitliliği geniş olması' (4.170) değişkeni ön plana çıkmaktadır. Beklenen hizmet kalitesi bakımından ise, 'Servisin ne zaman yapılacağ 1 hakkında bilgi verilmesi' (4.228) önemli bir değişkendir. Bölümün en yüksek skoru -0.021 ile "Mevcut şarap içeceklerin çeşitliliği geniş olması" en düşük skoru ise -0.083 ile "Servisin ne zaman yapılacağ 1 hakkında bilgi verilmesi" olarak tespit edilmiştir. Bağ işletmelerinin hizmetlerinin empati ve güvenilirlik açısından kalitesinin tespitinde kullanılan servqual skoru -0.0434 olarak hesaplanmıştır. Bu sonuca göre, bağ işletmeleri çalışanlarının misafirlere karşı sunduğu hizmetin yeterince empatik ve güvenilir olmadığı düşünülmektedir.

Güvence Boyutu: Bu boyutta tüm sorulara verilen cevaplar beklentinin üzerinde gerçekleştiği görülmektedir. Algılanan hizmet kalitesinin güven boyutu incelendiğinde, 'Şarap içeceği lezzetli olması' (4.387) ifadesi öne çıkmaktadır. Beklenen hizmet kalitesinde benzer şekilde, Şarap içeceği lezzetli olması' (4.333) ifadesi öne plana çıkmaktadır. Bu boyut içerisinde en düşük puan 0.105 ile 'Servis edilen şarap içeceği aromalı olması' ve en yüksek 0.054 ile 'Şarap içeceği lezzetli olması' olarak ortaya çıkmıştır. Bağ işletmelerine duyulan güven için algı ve beklenti ortalamaları ile hesaplanan Servqual skoru 0.078 olarak hesaplanmıştır. Bu sonuca göre güven boyutunda beklentiler karşılanmaktadır. Bu nedenle katılımcıların bağ işletmelerine duydukları güvenin yerinde olduğu söylenebilir. 
Tablo 4. Beklenti, Algılama ve SERVQUAL Puanları

\begin{tabular}{|c|c|c|c|c|c|c|}
\hline \multirow{3}{*}{$\begin{array}{l}\text { Hizmet Kalitesi İfadeleri } \\
\begin{array}{l}\text { Fiziksel Özellikler ve } \\
\text { Heveslilik }\end{array}\end{array}$} & \multicolumn{2}{|c|}{ Algılanan Değerler } & \multicolumn{2}{|c|}{ Beklenen Değerler } & \multicolumn{2}{|c|}{ Servqual Puanı } \\
\hline & \multirow[t]{2}{*}{ Ortalama } & \multirow{2}{*}{$\begin{array}{l}\text { Standart } \\
\text { Sapma }\end{array}$} & \multirow[t]{2}{*}{ Ortalama } & \multirow{2}{*}{$\begin{array}{l}\text { Standart } \\
\text { Sapma }\end{array}$} & \multirow[t]{2}{*}{ Fark } & \multirow[t]{2}{*}{ Ort. } \\
\hline & & & & & & \\
\hline $\begin{array}{l}\text { 1.Çalışanlar } \\
\text { giyinmiş. }\end{array}$ & 4.0942 & 0.92156 & 4.1184 & 0.82286 & -0.0242 & \\
\hline $\begin{array}{l}\text { 2.Personel işinde daha } \\
\text { profesyonel. }\end{array}$ & 4.0616 & 0.95337 & 4.1486 & 0.90435 & -0.087 & \\
\hline $\begin{array}{l}\text { 3.Çalışanlar yardım etmek } \\
\text { için daha istekli. }\end{array}$ & 4.1812 & 0.90843 & 4.2428 & 0.86704 & -0.0616 & \\
\hline $\begin{array}{l}\text { 4.Daha hızlı hizmet } \\
\text { verirler. }\end{array}$ & 3.9710 & 0.96062 & 4.1196 & 0.90464 & -0.1486 & \\
\hline $\begin{array}{l}\text { 5.Çalışanlar } \\
\text { nazikler. }\end{array}$ & 4.3116 & 0.79819 & 4.3080 & 0.81536 & 0.0036 & \\
\hline $\begin{array}{ll}\text { 6.Çalışanlar } & \text { şarap } \\
\text { hakkında bilgililer. } & \end{array}$ & 4.0725 & 0.94301 & 4.2029 & 0.92370 & -0.1314 & -0.156 \\
\hline $\begin{array}{l}\text { 7.Çalışanlar kişisel ilgi ve } \\
\text { özen gösterebilir. }\end{array}$ & 4.1014 & 0.95947 & 4.1594 & 0.88828 & -0.058 & \\
\hline $\begin{array}{l}\text { 8.Şarap içecekleri uygun } \\
\text { bir şekilde servis edilir. }\end{array}$ & 4.2935 & 0.85542 & 4.3587 & 0.78968 & -0.0652 & \\
\hline $\begin{array}{l}\text { 9.Personelin kiyafetleri } \\
\text { temiz olur. }\end{array}$ & 4.3043 & 0.81002 & 4.3587 & 0.78506 & -0.0544 & \\
\hline Empati ve Güvenirlik & Ortalama & $\begin{array}{l}\text { Standart } \\
\text { Sapma }\end{array}$ & Ortalama & $\begin{array}{l}\text { Standart } \\
\text { Sapma }\end{array}$ & Fark & Ort. \\
\hline $\begin{array}{l}\text { 15.Servisin ne zaman } \\
\text { yapılacağı hakkında bilgi } \\
\text { verebilirler. }\end{array}$ & 4.144 & 0.9538 & 4.228 & 0.911 & -0.083 & \\
\hline $\begin{array}{l}\text { 16.Çalışanlar çok özel } \\
\text { ihtiyacımı anlayabilirler. }\end{array}$ & 3.938 & 0.9302 & 3.974 & 0.920 & -0.036 & \\
\hline $\begin{array}{ll}\text { 17.Mevcut } & \text { şarap } \\
\text { içeceklerin çeşitliliği } & \text { geniş } \\
\text { olabilir. } & \end{array}$ & 4.170 & 0.8923 & 4.192 & 0.920 & -0.021 & -0.043 \\
\hline $\begin{array}{l}\text { 18.Tatma süreleri uygun } \\
\text { olabilir. }\end{array}$ & 4.112 & 0.9563 & 4.144 & 0.918 & -0.032 & \\
\hline Güvence & Ortalama & $\begin{array}{l}\text { Standart } \\
\text { Sapma }\end{array}$ & Ortalama & $\begin{array}{l}\text { Standart } \\
\text { Sapma }\end{array}$ & Fark & Ort. \\
\hline $\begin{array}{l}\text { 11.Şarap içeceği lezzetli } \\
\text { olabilir. }\end{array}$ & 4.387 & 0.7274 & 4.333 & 0.7706 & 0.054 & \\
\hline $\begin{array}{l}\text { 12.Servis edilen şarap } \\
\text { içeceği aromalı olabilir. }\end{array}$ & 4.050 & 0.9444 & 3.945 & 1.0165 & 0.105 & \\
\hline $\begin{array}{l}\text { 13.Şarap içeceklerinin tat } \\
\text { kalitesi yüksek olabilir. }\end{array}$ & 4.246 & 0.7366 & 4.170 & 0.8112 & 0.076 & 0.078 \\
\hline Toplam & & & & & & -0.121 \\
\hline
\end{tabular}




\section{Beklenen ve Algılanan Hizmet Kalitesi Arasında Fark}

Hizmet kalitesi ile algıladıkları hizmet kalitesi arasında farklılık olup olmadığını görmek için Wilxocon testi yapılmıştır. Bu test bağımlı gruplar t-testinin parametrik olmayan alternatifidir. Wilcoxon test istatistiğinin hesaplanmasında her müşterinin ölçülen iki değerinin farkı alınarak sıralama işlemi yapılır ve çıkan sonuçlar aşağıdaki tablolarda sunulmuştur.

Tablo 5. Beklenen ve Algılanan Fiziksel Hizmet Kalitesi Arasındaki Özellikler ve Heveslilik Boyutlarına İlişkin Wilcoxon Testi Sonuçları

\begin{tabular}{|l|l|l|l|l|l|}
\hline $\begin{array}{l}\text { Beklenen Fiziksel Özellikler ve } \\
\text { Heveslilik - Algılanan Fiziksel } \\
\text { Özellikler ve Heveslilik }\end{array}$ & $\mathbf{N}$ & $\begin{array}{l}\text { Sıra } \\
\text { Ortalaması }\end{array}$ & $\begin{array}{l}\text { Sıra } \\
\text { Toplamı }\end{array}$ & Z & $\mathbf{P}$ \\
\hline Negatif sıra & 89 & 73.83 & 6570.50 & & \multirow{2}{*}{0.529} \\
\hline Pozitif sıra & 56 & 71.69 & 4014.50 & 0.011 \\
\hline Eşit sıra & 131 & & & & \\
\hline Toplam & 276 & & & & \\
\hline
\end{tabular}

Tablo 5 incelendiğinde bağ işletmelerinin fiziksel özellikleri ve heveslilik boyutuna ilişkin beklenti ve algıları arasında anlamlı bir fark olduğu görülmektedir $(\mathrm{z}=-2.529 ; \mathrm{p}<0.05)$. Bu durumda H1 kabul edilmiştir. Fark puanlarının sıra ortalamaları ve toplamları dikkate alındığında farkın negatif sıralar lehinde olduğu söylenebilir.

Tablo 6. Beklenen ve Algılanan Hizmet Kalitesi Arasındaki Empati ve Güvenirlik Boyutlarına İlişkin Wilcoxon Testi Sonuçları

\begin{tabular}{|c|c|c|c|c|c|}
\hline $\begin{array}{l}\text { Beklenen Empati ve Güvenilirlik } \\
\text { - Algılanan Empati - Güvenilirlik }\end{array}$ & $\mathbf{N}$ & Sira Ortalaması & Sira Toplamı & $\mathbf{Z}$ & $\mathbf{P}$ \\
\hline Negatif sıra & 59 & 55.47 & 3273.00 & \multirow{4}{*}{-1.577} & \multirow{4}{*}{0.115} \\
\hline Pozitif sıra & 46 & 49.83 & 2292.00 & & \\
\hline Eşit sıra & 171 & & & & \\
\hline Toplam & 276 & & & & \\
\hline
\end{tabular}

Tablo 6 incelendiğinde bağ işletmelerin beklenen ve algılanan empati ve güvenirlik boyutuna ilişkin algıları arasında anlamlı bir fark olmadığı görülmektedir ( $\mathrm{z}=-1.577 ; \mathrm{p}>0.05)$. Bu durumda H2 ret edilmiştir. Fark puanlarının sıra ortalamaları ve toplamları dikkate alındığında farkın negatif sıralar lehinde olduğu söylenebilir.

Tablo 7. Beklenen ve Algılanan Hizmet Kalitesi Arasındaki Güvence Boyutuna İlişkin Wilcoxon Testi Sonuçları

\begin{tabular}{|c|c|c|c|c|c|}
\hline Güvence & $\mathbf{N}$ & Sira Ortalaması & Sira Toplamı & $\mathrm{Z}$ & $\mathbf{P}$ \\
\hline Negatif sıra & 8 & 41.13 & 329.00 & \multirow{4}{*}{-14.176} & \multirow{4}{*}{0.000} \\
\hline Pozitif sıra & 267 & 140.90 & 37621.00 & & \\
\hline Eşit sıra & 1 & & & & \\
\hline Toplam & 276 & & & & \\
\hline
\end{tabular}


Tablo 7 incelendiğinde bağ işletmelerin beklenen ve algılanan güvence boyutuna ilişkin algıları arasında anlamlı bir fark olduğu görülmektedir $(\mathrm{z}=-14.176$; $\mathrm{p}>0.05)$. Bu durumda H3 kabul edilmiştir. Fark puanlarının sıra ortalamaları ve toplamları dikkate alındığında farkın pozitif sıralar lehinde olduğu söylenebilir.

Buna göre çalışma hipotezlerine yönelik sonuçların yer aldığı özet tablo aşağıdaki şekliyle sunulmaktadir.

Tablo 8. Araştırma Hipotezlerine Yönelik Sonuçlar

\begin{tabular}{|l|l|}
\hline Araştırma Hipotezleri & Sonuç (Red/Kabul) \\
\hline $\begin{array}{l}\text { H1: Trakya Bağ Rotasında yer alan bağ } \\
\text { işletmelerinin sahip olduğu fiziksel özellik ve } \\
\text { çalışanlarının hevesliliği açısından, } \\
\text { işletmeleri ziyaret eden turistlerin } \\
\text { bekledikleri hizmet kalitesi ile algıladıkları } \\
\text { hizmet kalitesi arasında farklılık vardır. }\end{array}$ & \\
\hline $\begin{array}{l}\text { H2: Trakya Bağ Rotasında yer alan bağ } \\
\text { işletmelerinde çalışanların kurduğu empati } \\
\text { ve güvenirlik açısından, işletmeleri ziyaret } \\
\text { eden turistlerin bekledikleri hizmet kalitesi ile } \\
\text { algıladıkları hizmet kalitesi arasında farklılık } \\
\text { vardır. }\end{array}$ & \\
\hline $\begin{array}{l}\text { H3: Trakya Bağ Rotasında yer alan bağ } \\
\text { işletmelerindeki işletmelere duyulan güven } \\
\text { bakımından, işletmeleri ziyaret eden } \\
\text { turistlerin bekledikleri hizmet kalitesi ile } \\
\text { algıladıkları hizmet kalitesi arasında farklılık } \\
\text { vardır. }\end{array}$ & \\
\hline
\end{tabular}

\section{SONUÇ}

Trakya bağ rotasında bulunan işletmelerin hem kendi rotasında bulunan işletmeler hem de diğer rotalarda bulunan işletmeler ile rekabet içerisinde bulunması turistlerin istek ve ihtiyaçlarına uygun mal ve hizmet üretme zorunluluğunu doğurmaktadır. Bağları ziyaret eden turistler bir sorun yaşadıklarında yardım etmek için hevesli bir çalışan, güvenli hizmet sunan bir işletme, fiziksel olarak özenle hazırlanmış bir çalışan ve kendini müşteri yerine koyarak empati kurabilen bir çalışan beklemektedir. Bu nedenle bağ rotasında bulunan işletmelerin, müşterilerin hizmet almadan önceki beklentileri ve aldıktan sonraki (alg1) hizmet deneyiminin kıyaslanmasının sonucu hizmet kalitesinde ortaya çıkan boşlukları belirleyip müşteri memnuniyeti çerçevesinde sunulan hizmetin zayıf yönlerini saptaması önemlidir.

Benzer çalışmalarda olduğu gibi (Bruwer, 2003) turistlerin bağları ziyaret etmekteki en büyük amacı şarap tadımı ya da şarap satın alma gibi şarabın kendisine yönelik motivasyonlar olmaktadır. Çalışmadaki demografik bulgulara göre kadınlar erkeklere göre bağ ziyaretlerine gitmeyi ve şarap tadımı yapmayı daha çok tercih etmektedirler. Birçok çalışmada bağ ziyaretlerine ve şarap tadımlarına genellikle kadınların katıldığı görülürken ( $\mathrm{O}^{\prime}$ Neill ve Charters, 
2000; Bruwer ve Alant, 2009; Bruwer ve Kelley, 2015; Okech, 2016) yerli yazındaki bazı çalışmalarda (Ahipaşaoğlu ve Korkmaz, 2008; Demirkol vd., 2016) erkeklerin bağ rotası ya da şarap işletmeleri ziyaretini daha çok tercih ettiği ortaya çıkmıştır. Yaş aralığına bakıldığında ise, genç nüfus olarak nitelendirebileceğimiz ziyaretçilerin bağ işletmelerini daha çok ziyaret ettiği görülmektedir. Hemen arkasından orta yaşa sahip turistlerin bağları ziyaret ettikleri bulunmuştur. Ahipaşaoğlu ve Korkmaz (2008), Bruwer ve Kelley (2015), Okech (2016) ve Haverila ve arkadaşları (2020) çalışmalarında orta yaş ziyaretçilerin tercih ettiğini belirtmektedir. Bu sonuçlardan dolayı, şarap turistlerinin genç ve orta yaş nüfustan oluştuğu söylenebilir. Ayrıca demografik sonuçlara bakıldığında şarap turizmini gelir düzeyi yüksek olan kişiler tercih etmektedir. Bu sonuç da yine diğer çalışma bulgularıyla desteklenmektedir ( $\mathrm{O}^{\prime} \mathrm{Neill}$ ve Charters, 2000; Demirkol vd., 2016). Böylece şarap turizminin katma değeri yüksek alternatif bir turistik ürün olduğunu söylemek mümkündür. Eğitim durumuna bakıldığında katılımcların neredeyse yarısının üniversite mezunu olduğu, geri kalan büyük çoğunluğunun ise lisansüstü eğitim derecesine sahip olduğu görülmektedir. Bu bulgular da benzer çalışmalarla desteklenmektedir (Ahipaşaoğlu ve Korkmaz, 2008; Demirkol vd., 2016; Ergüven vd., 2016). Bu nedenle Mitchell ve Hall (2006) tüketicilerin şarap bilgilerini artırmak için şaraphane ziyaretlerinin eğitim işlevine daha fazla dikkat edilmesi gerektiğini öne sürmektedir. Bu kapsamda şarap turisti grupları için özel şarap tadımı ve eğitim etkinlikleri düzenlenebilir.

Sonuçlara göre müşteri beklentileri ile algılanan hizmet kalitesi arasında oluşan en büyük farklar servqual fark puan ortalamalarına göre sırasıyla fiziksel özellikler ve heveslilik, güvence, son olarak empati ve güvenirlik olmuştur. Elde edilen bu sonuç O' Neill vd., (2002), Jinling (2007), Alroub vd., (2012) ve Fettahlıoğlu vd., (2016)'nın çalışmalarından elde edilen bulgularla benzerdir. Öte yandan, bazı araştırmalarda bu boyutların farklı bir şekilde sıralandığını söylemek mümkündür. Bazı çalışmalarda güvenirlik boyutunun ilk sırada yer aldığı görülürken (Aksu vd., 2016), bazı çalışmalarda heveslilik (Bilgin ve Kethüda, 2017) ya da fiziksel özelliklerin ilk sırada geldiği (Haverila vd., 2020) görülmektedir. Performansı artırmanın en önemli yolu, yüksek kaliteli ve sürekli bir personel eğitim programı sağlamak, müşterilerle empati ve duyarlılık gibi boyutlarda hizmet kalitesinin sunulmasını garanti etmektir. Fiziksel özellikler ve heveslilik boyutunda büyük fark çıkması hem işletmelerin sahip olduğu fiziki görünüm ve ekipman açısından yetersiz olduğunu hem de personelin kaliteli ve profesyonel bir şekilde hizmet sunma yeteneğine ve bilgisine sahip olmadığını göstermektedir. Beklenti ve algı arasında oluşan en az fark ise empati ve güvenilirlik boyutunda oluşmuştur. Bunun sonucunda bağdaki misafirlerin çalışanlardan beklediği kendilerini misafirlerin yerine koyup sunulan hizmetin bekledikleri gibi gerçekleşmesidir. Bu nedenle işletmelerdeki çalışanların servis, şarap sunumu gibi çeşitli teknik kurslara tabi tutulurken davranış içerikli empati ve iletişim kurma becerilerini destekleyen kurslara da katılımlar hem kurum içi hem kurum dışı olacak şekilde desteklenmelidir. Böylece, bağ işletmelerindeki personelin servis hakkında bilgi vermesi, misafirlerle empati kurabilmesi, vaat edilen hizmetlerin sunulması ziyaretçilerin bağ işletmelerine gelmesinde büyük katkı sağlayacaktır.

Wilcoxon analiz sonuçlarına göre, ziyaretçilerin bağ işletmelerinden hizmet kalitesi konusunda beklediği fiziksel özellikler ve heveslilik değer algısının deneyimlenen fiziksel özellikler ve heveslilik algısından negatif yönlü ayrıştı̆̆ görülmektedir. Şarap turistlerinin çoğu işletmelerden beklediği fiziksel özellikler ve heveslilik değerleri konusunda yeterli tatmini bulamamıştır. Lee ve diğerleri (2016)'nın yaptıkları araştırma sonucunda hizmet kalitesi fiziksel özellikleri boyutunun Çinli şarap turistlere göre memnuniyetlerinde bir rol oynamadığı görülmüştür. Tam tersi, Jinling (2007) ve Bilgin ve Kethüda (2017) araştırmalarında heveslilik boyutunda müşteri beklentilerinin çok üzerinde hizmet sunulduğu sonucuna varmıştır. Çalışanların iş bilgisinin yüksek olması sebebiyle yardımcı olmayı istemeleri beklenti ve algı arasında fark olduğunu 
ortaya koymaktadır. Ayrıca Igreja vd., (2020) çalışmasında otel misafirlerinin algı ve beklenti arasında farklılıklar olduğu sonucuna varmıştır. Çalışmada ziyaretçilerin bağ işletmelerinden hizmet kalitesi konusunda beklediği empati ve güvenirlik boyutunun, algilanan empati ve güvenirlik boyutundan negatif yönlü ayrıştığı ortaya çıkmaktadır. Buna göre, şarap turistlerinin çoğu işletmelerden beklediği empati ve güvenirlik değerleri konusunda yeterli tatmini bulamamıştır. Sadece güvence boyutunda ziyaretçilerin bağ işletmelerinin hizmet kalitesi konusunda beklediği güvence boyutunun, algılanan güvence boyutundan pozitif yönlü ayrıştığı ortaya çıkmıştır. Bu kapsamda şarap turistlerinin çoğunun, işletmelerin onlara sunduğu güvence konusunda tatmin olduğu söylenebilmektedir. Ahipaşaoğlu ve Korkmaz (2008) araştırmasında ise misafirlerin şarap tadımına ilişkin değerlerin beklenti ve algı arasında farklılaşmadığ sonucuna ulaşmıştır.

Sonuç olarak Trakya bağ rotasında bulunan işletmelerde güvence değerine yönelik müşteri memnuniyetinin gün geçtikçe artacağı söylenebilir. Ancak bağ işletmelerindeki fiziksel özellikler ve heveslilik, empati ve güvenirlik boyutlarına yönelik müşteri memnuniyetinin zamanla düşeceği söylenebilir. Şarap üreticilerinin ve Bağ işletmecilerinin hizmet kalitesi boyutlarına ilişkin müşteri memnuniyetinin olumlu bir şekilde ilerlemesini sağlayan en iyi önlem müşteri algılarının tespit edilmesidir. İşletmecilerin veya yöneticilerin empati ve güvenirlik, fiziksel özellikler ve heveslilik boyutlarını detaylıca incelemeleri, müşterilerin memnuniyet algılarını öğrenmeleri bakımından fayda sağlayacaktır. Bu anlamda çalışanların problemlere karşı pratik çözümler sunabilmeleri, çalışanların kendi hizmet beklentilerini göz önünde bulundurarak müşterileri kendi yerine koyarak davranmaları, çalışanların temiz ve hijyenik olmaları gibi fiziksel olanaklar yönünden beklentileri karşılayan bir işletmede hizmet vermeleri gibi yöntemlerle gerekli tedbiri almaları önerilmektedir. Tüm bunlara ek olarak çalışanların, şarap ve şarabın sunulması konusunda kurslara gönderilmesi önem arz etmektedir. Bu doğrultuda işletmelerin gerekli önlemleri almaları ve öncelikle hizmet kalitesini net bir şekilde tanımlamaları gerekmektedir. Hizmet kalitesi felsefesini tüm işletme özelliklerine ve çalışanlarına yansıtacak bir yönetim anlayışı benimsemelidirler. Bunun için en iyi kaynaklardan biri turistlerin algılarının ve beklentilerinin neler olduğunun değerlendirilmesi olacaktır. Buna göre işletmeler beklenti ve algı arasında oluşacak boşlukları önceden görebilir ve ona göre önlemlerini alabilirler. Sundukları hizmetin kalitesini arttırmaya yönelik çalışmaları gerçekleştirebilirler.

Şarap turistlerinin gelir düzeyi yüksek olduğundan bekledikleri hizmet kalitesi de yüksektir. Eğitim seviyesi de yüksek olan şarap turistleri deneyim yoluyla öğrenmeyi ve tatillerini ve zevklerini buna göre geliştirmeyi tercih edeceklerdir. Bu nedenle bağ işletmelerinin hizmetlerini sunacağı çeşitli workshop, atölye çalışmaları ve ünlü şarap uzmanlarının sunumları ile şekillendirmesi yerinde olacaktır. Çevre gezileri, tarihi-kültürel noktalara ziyaret gibi rekreatif faaliyetler ürün çeşitlendirmesi yaratarak sunulan hizmeti zenginleştirebilecektir. Bağ çalışanlarının gelen misafirlere karşı şarap hakkında bilgi vermeleri, şarap-yemek uyumu konularına hakim olmaları ve bunu sundukları hizmetle harmanlamaları yerinde olacaktır. Çalışanın iyi bir şekilde eğitilmesi, sunum sırasında kullandığı ekipmanlara hakim olması, hizmet konusunda ve misafirin problemlerini çözme konusunda hevesli olması, kendini misafirin yerine koyabilmesi ile misafir memnuniyetinin arttırılması mümkündür.

Çalışma hem yabancı literatürde hem de yerli literatürde bağ işletmelerindeki hizmet kalitesinin beklenti ve algı arasındaki ilişkileri otaya koyan ender çalışmalar arasında yer almaktadır. Ayrıca Trakya Bağ Rotası açısından bu ilişkileri inceleyen başka bir çalışmaya rastlanmamıştır. Bu nedenle bu çalışma, alandaki boşluğu doldurması ve yapılacak diğer çalışmalara örnek olması sebebiyle önem taşımaktadır. Çalışmanın akademik katkısını ileriye taşıyabilmek için daha fazla turist sayısına ulaşarak elde edilen bulgular tekrar değerlendirilebilecek, çalışmada yer alan 
işletmelerin hizmet kalitesi karşılaştırılabilecek ve böylece işletmelerin birbirinden öğrenmesi sağlanabilecektir.

\section{KAYNAKÇA}

Ahipaşaoğlu, S. and Korkmaz, E. (2008). Service Quality Perceptions of the Tourists Participating Wine Tourism: A Research at Cappadocia Region, Journal of Tourism Research, 3: 72-104.

Akdağ, G. (2015). Trakya Bağ Rotasını Takip Eden Yerli Turistlerin Şarap Turizmi Deneyimleri, Journal of Tourism and Gastronomy Studies, 3(4): 3-11.

Aksu, M., Korkmaz, H. ve Sünnetçioğlu, S. (2016). Yiyecek ve İçecek İşletmelerindeki Hizmet Kalitesinin Müşteri Memnuniyeti Üzerinde Etkisi: Bozcaada'da Dineserv Modeliyle Araştırma, Balıkesir Üniversitesi Sosyal Bilimler Enstitüsü Dergisi, 35(19): 1-18.

Albattat, A. and Romli, S. R. M. (2017). Determining Visitors' Repetition by Using Servqual Dimensions in Attraction Parks: A Case from Kuala Lumpur, Malaysia, International Journal of Applied Business and Economic Research, 15(15): 351-372.

Albayrak, A. (2013). Alternatif Turizm, Ankara: Detay Yayıncllı.

Alroub, A. S. A., Alsaleem, A. S. M. and Daoud, A. A. (2012). Service Quality and Its Impact on Customer Satisfaction Tourist Restaurants (A Field Study on The Tourist Restaurants / Amman), Interdisciplinary Journal of Contemporary Research in Busines, 4 (1): 364-379.

Altan, Ş. ve Atan, M. (2004). Bankacıllk Sektöründe Toplam Hizmet Kalitesinin Servqual Analizi ile Ölçümü, G.Ü.I.İ.B.F Dergisi, 1: 17-32.

Bako, A. G. (2016) Alternatif Turizm Kapsamında Şarap Turizmi: Manisa/Kula'yı Ziyaret Eden Şarap Turistlerine Yönelik Bir İnceleme. Yayımlanmamış Yüksek Lisans Tezi, Mersin Üniversitesi, Mersin.

Bayat, G. ve Polat, M. (2019). Otel İşletmelerinde Sunulan Hizmet Kalitesinin Servqual Yöntemi ile Ölçülmesi, Ĭğdır Üniversitesi Sosyal Bilimler Dergisi, 20: 557-578.

Becker, C. (1984). Wine tourism on the Moselle. Berichte zur Deutschen Landeskunde, 58(2): 381-407.

Bilgin, Y. ve Kethüda, Ö. (2017). Restoran İşletmelerinde Hizmet Kalitesinin Müşteri Memnuniyetine ve Sadakatine Etkisi: Oba Restoran Örneği, Çankırı Karatekin Üniversitesi ve İdari Bilimle Fakültesi Dergisi, 7(2): 147-170.

Brochado, A., Stoleriu, O. and Lupu, C. (2019). Wine tourism: a multisensory experience, Current Issues in Tourism, 24(5): 597-615.

Brown, G. and Getz. D. (2005). Linking Wine Preferences to the Choice of Wine Tourism Destinations, Journal of Travel Research, 43: 266-276.

Brown, G. P., Havitz, M. E. and Getz, D. (2007). Relationship between wine involvement and wine related travel, Journal of Travel and Tourism Marketing, 21(1): 31-46.

Bruwer, J. (2003). South African wine routes: Some perspectives on the wine tourism industry's structural dimensions and wine tourism product, Tourism Management, 24(4): 423-435.

Bruwer, J. and Alant, K. (2009). The hedonic nature of wine tourism consumption: An experiential view. International Journal of Wine Business Research, 21(3): 235 -257.

Bruwer, J. and Kelley, K. (2015). Service Performance Quality Evaluation and Satisfaction in A USA Wine Festivalscape Buying Behavioural Effects, International Journal of Event and Festival Management, 6 (1): 18-38. 
Budianto, A. (2019). Customer Loyalty: Quality of Service, Journal of Management Review, 3(1): 299305.

Carlsen, J. and Charters, S. (2006). Global Wine Tourism, Research, Management and Marketing, CAB International Nosworthy way UK.

Chaturvedi, R. K. (2017). Mapping Service Quality in Hospitality Industry: A Case through SERVQUAL. Asian Journal of Management, 8(3): 1-11.

Chou, C-C., Liu, L-J., Huang, S-F., Yih, J-M. and Han, T-C. (2011). An evaluation of airline service quality using the fuzzy weighted SERVQUAL method, Applied Soft Computing, 11: 2117-2128.

Cronin, J. J. C., Joseph J. J. and Taylor S. A. (1992). Measuring Service Quality: A Reexamination and Extension, Journal of Marketing, 56 (3): 55-58.

Demirkol, C., Salha, H. ve Cinnioğlu, H. (2016). Trakya Bağ Rotasına Gelen Turistlerin Profilinin Belirlenmesine Yönelik Bir Araştırma. Balkan ve Yakın Doğu Sosyal Bilimler Dergisi, 2(4): 109-120.

Duran, E., Eryücel, Ö. ve Özcan, Z. (2019). Şarap Üretimi ve Tüketiminin Türkiye Turizmindeki Yeri: Kadim Anadolu Bağ Rotası Başlangıç Noktası Olarak Çanakkale Örneği, Turizm ve Araştırma Dergisi, 8(1): 70-83.

Ergüven, M. H., Ergüven, A. T. and Yılmaz, A. (2016). Leisure Time Activities of Crème De La Crème Tourists: The Case of Thrace Vineyard Route. International Journal of Social Science, 52: 273284.

Ertürk, M. (2011). Türkiye'deki Otel İşletmelerinde Hizmet Kalitesinin Ölçülmesine Yönelik Bir Alan Araştırması, Yayınlanmamış Doktora Tezi, Gazi Üniversitesi, Ankara.

Eshghi, A., Roy, S. K. and Ganguli, S. (2008). Service Quality and Customer Satisfaction: An Empirical Investigation in Indian Mobile Telecommunications Services, Marketing Management Journal, 18(2): 119-144.

Etyemez S. ve Özyılmaz A. (2012). Gastronomi Turizmi ve Hatay Mutfak Kültürü, 1. Doğu Akdeniz Seтроzуumu, Mersin, 20-22 Nisan, ss: 124-136.

Fettahlığlu, O. Ö., Polat, M. ve Demir, S. (2016). Hizmet Kalitesinin Servqual Analizi ile Ölçümü: Kahramanmaraş İlinde Bir Uygulama, Ordu Üniversitesi Sosyal Bilimler Araştırmaları Dergisi, 6(3): 849-860.

Filiz, Z. (2011). Servqual Yöntemiyle Yurt İşletmesinde Hizmet Kalitesinin Ölçülmesi, International Journal of Research and Development, 3(1): 38-49.

Filiz, Z., Yılmaz, V. ve Yağızer, C. (2010). Belediyelerde Hizmet Kalitesinin Servqual Analizi ile Ölçümü: Eskişehir Belediyelerinde Bir Uygulama, Anadolu Üniversitesi Sosyal Bilimler Dergisi, 10(3): 59-76.

Freitas, B. J., Martin, C. J. and Roman, C. (2017). Service quality evaluation in the perception of the wine tourist with Fuzzy Logic and Ideal Solutions, Revista de Turismo y Patrimonio Cultural, 15(2): 341-358.

Getz D. and Brown, G. (2006) Critical Success Factors for Wine Tourism Regions: A demand Analysis, Tourism Management, 27(1): 147-148.

Ghylin, K. M., Green, B. D., Drury, C. G., Chen, J., Schultz, J. L., Uggirala, A. and Lawson, T. A. (2008). Clarifying the Dimensions of Four Concepts of Quality, Theoretical Issues in Ergonomics Science, 9(1): 73-94. 
Gilbert, D. C. (1992). Touristic development of a viticultural region of Spain. International Journal of Wine Marketing, 4(2): 25-32.

Gross, M. J., and Brown, G. (2006). Tourism experiences in a lifestyle destination setting: The roles of involvement and place attachment, Journal of Business Research, 59(6): 696-700.

Grönroos, C. (1984). A Service Quality Model and Its Marketing Implications, European Journal of Marketing, 18 (4): 36-4.

Hall, C. M., Cambourne, B., Macionis, N. and Johnson, G. (1997). Wine tourism and network development in Australia and New Zealand: Review, establishment and prospects, International Journal of Wine Marketing, 9(2/3): 5-31.

Hall, C. M and Weiler, B. (1992). What's Special About Special Interest Tourism? in B. Weiler and C. M. Hall (Editörler), Special Interest Tourism (ss. 1-14). London: Belhaven Press.

Haverila, M., Haverila, M. and Arora, M. (2020). Comparing the service experience of satisfied and non-satisfied customers in the context of wine tasting rooms using the SERVQUAL model, International Journal of Wine Business Research, 30(2): 301-324.

Igreja, C., Silva, T. and Sousa, B. (2020). Compreendendo a qualidade do serviço em contextos específicos do enoturismo: um estudo exploratório, European Journal of Applied Business Management, IWTHM Special Issue: 42-54.

Jinling, L. (2006). Service Quality of Travel Agencies in Taiwan, Tourism and Leisure Management, 96 (22): 271-278.

Jinling, L. (2007). Measuring Service Quality of the Leisure Winery Industry : A Taiwan Based Study. [online] http://web.nanya.edu.tw/tcof/tcrd/word, [Erişim Tarihi: 21.02.2021].

Kozak, A. M. ve Bahçe, A. S. (2012). Özel İlgi Turizmi, Ankara: Detay Yayıncılık.

Kusonwattana, P. and Liangrokapart, J. (2020). Efficiency Enhancement in Rail Freight Service in Thailand Using Servqual Model, 2020 IEEE 7th International Conference on Industrial Engineering and Applications (ICIEA): 847-853.

Küçükaltan, D., Küçükaltan, B. ve Artuner Özder, C.G. (2017). Turizm İşletmelerinde Kalite Yönetimi, Ankara: Detay Yayıncilık.

Lee, K., Madanoglu, M. and Youn Ko, J. (2016). Exploring key service quality dimensions at a winery from an emerging market's perspective, British Food Journal, 118 (12): 2981-2996.

Min, H. and Min, H. (1997). Benchmarking the quality of hotel services: managerial perspectives, International Journal of Quality \& Reliability Management,14 (6): 582-597.

Mitchell, R. and Hall, C. M. (2006). Wine tourism research: The state of play. Tourism Review International, 9: 307-332.

OIV. (2019). Statistical Report on World Vitiviniculture. [online] https://www.oiv.int/public/medias/6782/oiv-2019-statistical-report-on-world-vitiviniculture.pdf. [Erişim Tarihi: 15.02.2021].

Okech, R. N. (2016). Developing Wine Tourism: An Exploratory Study of Wineries in Newfoundland, Advances in Hospitality and Tourism Research (AHTR), 4(1): 70-82.

O'Neill, M. and Charters S. (2000). Service quality at the cellar door: implications for Western Australia's developing wine tourism industry, Managing Service Quality, 10(2): 112-122. 
O'Neill, M., Palmer, A. and Charters, S. (2002). Wine production as a service experience - the effects of service quality on wine sales, Journal of Services Marketing, 16(4): 342-362.

Ömür, M. (2016). Türk Şarapcillğg 2016 Raporu. [online] https://docplayer.biz.tr/26180847Mehmet-omur-turk-sarapciligi-2016-raporu.html, [Erişim Tarihi: 14.02.2021].

Öztürk, Y. ve Seyhan K. (2005). Konaklama İşletmelerinde Sunulan Hizmet Kalitesinin Servqual Yöntemi ile Ölçülmesi, Anatolia: Turizm Araştırmaları Dergisi, 16(2): 170-182.

Pakdil, F. and Aydin, O. (2007). Expectations and perceptions in airline services: an analysis using weighted SERVQUAL scores, Journal of Air Transport Management, 13: 229-237.

Parasuraman, A., Zeithaml, V. A. and Berry, L. L. (1985). A Conceptual Model of Service Quality and its Implications for Future Research, The Journal of Marketing, 49: 41-50.

Parasuraman, A., Zeithaml, V. A., and Berry, L. L. (1988). SERVQUAL: A Multiple-Item Scale for Measuring Consumer Perceptions of Service Quality, Journal of Retailing, 64: 12-40.

Puri G. and Singh, K. (2018). The Role of Service Quality and Customer Satisfaction in Tourism Industry: A Review of Servqual Model. International Journal of Research and Analytical Reviews, 5(4): 745-751.

Rahman, S., Erdem, R. ve Devebakan, N. (2007). Hizmet Kalitesinin Servqual Ölçeği ile Değerlendirilmesi: Elazığ'daki Hastaneler Üzerinde Bir Çalışma, Dokuz Eylül Üniversitesi Sosyal Bilimler Enstitüsü Dergisi, 9(3): 37-55.

Saadillah, D. and Syairudin, B. (2019). Analysis of the Effect of Service Quality on Satisfaction of Visitors of Blitar Agrotourism Using Servqual, IPTEK Journal of Proceedings, 5: 104-113.

Salha, H. ve Cinnioğlu, H. (2018). Hygge Hizmet Felsefesinin Bağ Evlerinde Uygulanabilirliği: Trakya Bağ Rotası Tekirdağ Bağları Örneği, 1.Uluslararası Turizmde Yeni Jenerasyonlar ve Yeni Trendler Konferansı, 1-3 Kasım 2018, Sakarya.

Shafiq, A., Mostafiz, Imtiaz, Md., and Taniguchi, M. (2019). Using SERVQUAL to Determine Generation Y's Satisfaction Towards Hoteling Industry in Malaysia, Journal of Tourism Futures, 5(1): 62-74.

Šíma, J., Čáslavová, E. and Crossan, W. (2020). Using an enhanced SERVQUAL approach to assess service quality in Czech fitness centers, Auc Kinanthropologica, 56(2): 143-159.

Wang, L., Y., Luor, T., Luarn, P. and, Lu, P., H. (2015). Contribution and Trend to Quality Research a Literature Review of SERVQUAL Model From 1998 to 2013, Informatica Economica, 19(1), 34-45.

Yıldız, Ö. E. (2009). Türkiye'de Şarap Turizmi. Çeşme Örneğinde Ürün Geliştirme Modeli, Yayımlanmamış Yüksek Lisans Tezi, Dokuz Eylül Üniversitesi, İzmir.

Yüncü, H. R. (2010). Şarap Turizmi Bölgelerinin Rekabet Edebilirliğine Yönelik Bir Model Önerisi: Kapadokya Örneği, Yayımlanmamış Doktora Tezi, Anadolu Üniversitesi, http://ulusaltezmerkezi.com.

Zeithaml, V. A. (1988). Consumer Perceptions of Price, Quality and Value: A Means End Model and Synthesis of Evidence, The Journal of Marketing, 52(3): 2-22. 